Louise Fréchette

Reflections on Working with Defenses and Resistances in the Context of Teletherapy

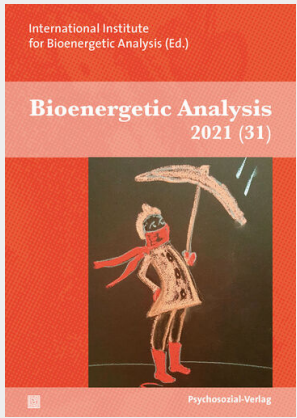

Bioenergetic Analysis

31. Volume, No. 1, 2021, Page 23-37

Psychosozial-Verlag

DOI: 10.30820/0743-4804-2021-31-23 
Reviewers for this issue:

Léia Cardenuto, Garry Cockburn, Maê Nascimento and M. Rosaria Filoni

Translators of abstracts for this issue:

Angelina Samartova (Russian), Claudia Ucros (French), Karin de Marval (Spanish), Maê Nascimento (Portuguese), Maria Rosaria Filoni (Italian), Thomas Heinrich (German) and Rebecca Jianpu Liu (Chinese)

Submissions for consideration for the next volume of Bioenergetic Analysis must be sent to Maê Nascimento (maenascimento@terra.com.br) between June $1^{\text {st }}$ and September $1^{\text {st }}$, 2021.

Bibliographic information of Die Deutsche Nationalbibliothek (The German Library) The Deutsche Nationalbibliothek lists this publication in the Deutsche Nationalbibliografie; detailed bibliographic data are available at http://dnb.d-nb.de.

2021 Psychosozial-Verlag, Gießen, Germany

info@psychosozial-verlag.de

www.psychosozial-verlag.de

\section{(C) $(1) \Theta$}

This work is licensed under the Creative Commons Attribution-NonCommercialNoDerivatives 4.0 International License (CC BY-NC-ND 4.0). This license allows private use and unmodified distribution, but prohibits editing and commercial use (further information can be found at: https://creativecommons.org/licenses/by-nc-nd/4.0/). The terms of the Creative Commons licence only apply to the original material. The reuse of material from other sources (marked with a reference) such as charts, illustrations, photos and text extracts may require further permission for use from the respective copyrights holder.

Cover image: Vincentia Schroeter, Umbrella girl (c) Vincentia Schroeter Cover design \& layout based on drafts by Hanspeter Ludwig, Wetzlar Typesetting: metiTec-Software, me-ti GmbH, Berlin, www.me-ti.de

https://doi.org/10.30820/0743-4804-2021-31

ISBN (PDF-E-Book) 978-3-8379-7809-4

ISBN (Print) 978-3-8379-8363-0

ISSN (Online) 2747-8882 • ISSN (Print) 0743-4804 


\title{
Reflections on Working with Defenses and Resistances in the Context of Teletherapy ${ }^{1}$
}

\author{
Louise Fréchette
}

Bioenergetic Analysis • The Clinical Journal of the IIBA, 2021 (31), 23-37

https://doi.org/10.30820/0743-4804-2021-31-23

CC BY-NC-ND 4.0

www.bioenergetic-analysis.com

\section{Abstracts}

This article focuses on the challenges we face as bioenergetic therapists when doing teletherapy. It addresses the difficulty of working with defenses and resistances in a context where the client is not physically present and where we only see part of the body through a screen, in a two-dimensional representation (sessions on video) or not at all (phone sessions). It offers practical suggestions to compensate for what cannot be apprehended directly due to distant communication. It also offers some research data on the level of efficacy and on the quality of the relationship, when teletherapy is compared with face-toface therapy. Finally, it offers practical suggestions with regards to visual fatigue and as well as some elements of understanding Zoom fatigue.

Keywords: teletherapy, face-to-face therapy, resistances, capacities and limitations, research

Reflexões no trabalho com as defesas e resistências no contexto da tele terapia (Portuguese)

Este artigo está focado nos desafios que temos que encarar enquanto terapeutas bioenergéticos fazendo tele terapia. Ele se debruça sobre as dificuldades em trabalhar com defesas e resistências num contexto em que o cliente não está fisicamente presente e onde vemos apenas parcialmente o corpo desse cliente através da tela, numa representação bidimensional (sessões em vídeo) ou até nenhuma imagem (sessões pelo telefone). Ele sugere sugestões práticas a fim de compensar pelo que não poderá ser compreendido diretamente devido à distância. Ele oferece também alguns dados de pesquisa a nível da

1 "Teletherapy" means all kinds of distance communication, be it of a video type (FaceTime, Reacts, Zoom, Skype, etc.), instant messaging (texting), or of an audio type (phone). 
eficácia e da qualidade dos relacionamentos, na medida em que a tele terapia é comparada com a terapia face a face. Por fim, ele oferece sugestões práticas em se considerando a fadiga visual bem como a alguns elementos específicos ao entendimento da fadiga do zoom.

\section{Reflexiones sobre el trabajo con defensas y resistencias en el contexto de la psicoterapia virtual (Spanish)}

Este artículo enfoca el desafío que enfrentamos como terapeutas bioenergéticos en la práctica de la psicoterapia virtual. Aborda la dificultad de trabajar con defensas y resistencias en el contexto en el cual el paciente no está fisicamente presente y apenas vemos parte de su cuerpo en la pantalla en una representación bidimensional (sesiones por videollamadas) o no lo vemos en absoluto (sesiones telefónicas). Propone sugerencias prácticas que compensen lo que no puede ser captado directamente en una terapia cara a cara. Plantea también una investigación sobre el nivel de eficacia y sobre la cualidad de la relación, comparado con la terapia presencial. Finalmente, nos ofrece sugerencias prácticas con una mirada sobre el cansancio visual y elementos para comprender la fatiga provocada por el zoom.

Riflessioni sul lavoro con le difese e le resistenze nel lavoro in remoto (Italian) Questo articolo riguarda le sfide con cui ci confrontiamo, come terapeuti bioenergetici, quando lavoriamo in remoto. Affronta le difficoltà nel lavoro con le difese e le resistenze quando il cliente non è fisicamente presente e vediamo solo una parte del corpo attraverso lo schermo in una rappresentazione bidimensionale (sedute in video), o non lo vediamo affatto (sedute telefoniche). Offre suggerimenti pratici per ovviare a ciò che non può essere appreso direttamente a causa della comunicazione a distanza e dati che provengono dalla ricerca sul livello di efficacia e la qualità della relazione quando il lavoro in remoto è paragonato con quello in presenza. Infine, offre suggerimenti pratici sulla fatica visiva ed elementi per comprendere la Zoom fatigue.

Réflexions sur le travail avec les défenses et les résistances dans le contexte de la téléthérapie (French)

Cet article se concentre sur les défis auxquels nous sommes confrontés en tant que thérapeutes bioénergétiques dans le cadre de la téléthérapie. Il aborde la difficulté de travailler avec les défenses et les résistances dans un contexte où le client n'est pas physiquement présent et où nous ne voyons qu'une partie du corps à travers un écran, dans une représentation bidimensionnelle (séances sur vidéo) ou pas du tout (séances téléphoniques). Il offre des suggestions pratiques pour compenser ce qui ne peut pas être directement appréhendé en raison de la communication à distance. Il propose également quelques données de recherche sur le niveau d'efficacité et sur la qualité de la relation, lorsque la téléthérapie est comparée à la thérapie en face à face. Enfin, il fournit des recommandations pratiques concernant la fatigue visuelle totale ainsi que quelques éléments de compréhension sur la fatigue liée à l'utilisation de Zoom. 


\section{Reflexionen zur Arbeit mit Abwehr und Widerständen im Kontext von medial vermittelter Psychotherapie (German)}

Dieser Artikel konzentriert sich auf die Herausforderungen, denen wir als bioenergetische Therapeut*innen begegnen, wenn wir Therapien medial vermittelt durchführen. Er befasst sich mit der Schwierigkeit, mit Abwehr und Widerständen in einem Kontext $\mathrm{zu}$ arbeiten, in dem der Klient nicht physisch anwesend ist und in dem wir entweder nur einen Teil des Körpers in einer zweidimensionalen Darstellung durch einen Bildschirm sehen (Sitzungen per Videochat) oder überhaupt nicht (Sitzungen per Telefon). Er bietet praktische Vorschläge, um das zu kompensieren, was aufgrund der medial vermittelten Kommunikation nicht direkt wahrgenommen werden kann. Er bietet auch einige Forschungsdaten zum Grad der Wirksamkeit und zur Qualität der Beziehung, wenn medial vermittelte Therapie mit Face-to-Face-Therapie verglichen wird. Schließlich bietet er praktische Vorschläge bezüglich visueller Ermüdung und einige Erklärungsansätze zur Zoom-Müdigkeit.

\section{РАЗМЫШЛЕНИЯ О РАБОТЕ С ЗАЩИТАМИ И СОПРОТИВЛЕНИЕМ ПРИ ДИСТАНЦИОННОЙ ТЕРАПИИ (Луиза Фрешетm) (Russian)}

В статье внимание сфокусировано на проблемах, с которыми сталкивается биоэнергетический терапевт при дистанционной терапии. Рассмотрена сложность работы с защитой и сопротивлением в условиях, когда клиент не присутствует физически и мы видим только часть его тела на экране в двухмерной проекции (сеансы по видеосвязи) или не видим вообще (сеансы по телефону). Предложены практические советы, как компенсировать то, что при удаленном общении невозможно уловить непосредственно. Также приведены данные исследований об уровне эффективности и качестве отношений при дистанционной терапии по сравнению с терапией с непосредственным контактом. В конце даны практические рекомендации касательно тотальной зрительной усталости, а также некоторых аспектов усталости от Zoom.

\section{在治疗情境下与防御和阻抗工作的反思 (Chinese)}

本文聚焦于作为一个躯体动力分析治疗师在工作中所面临的挑战。在当下的一个二维的 (网络咨 询 ) 治疗情境下，案主不能出现在治疗室，治疗师只能通过屏幕看到案主部分的身体，甚至根本 看不到画面 (电话咨询)，对于此种情况下治疗师与案主的防御和阻抗工作的困难，本文提供了 一些可操作的用于补偿由于远程交流而无法直接理解的部分的建议；也提供了一些和地面咨询相 对比后的有效性和关系品质的研究数据。最后，对于有关视觉疲劳和一些理解网络疲劳的因素也 提出了可行的建议。 


\section{Introduction}

As Bioenergetic Analysis therapists, we are well-trained to notice moments when a resistance arises in the course of a face-to-face therapy session, and to interpret such resistance within the framework of the characterological defense system of our clients. Teletherapy work, however, poses an additional challenge in that respect. When we do face-to-face therapy sessions in bioenergetic analysis, all the bodily cues are accessible to us as the person in their totality is present in our immediate visual, auditive, olfactive and kinesthetic perceptual field. This is not the case when we do teletherapy.

But let's start at the beginning. When we must offer a client to do teletherapy sessions as opposed to face-to-face ones, like we were forced to do during the confinement measures of the 2020 Spring, elements of resistance may manifest themselves right from the start. These resistances may be triggered by various factors. For example:

$>$ Lack of ease with technological means

$>$ Distrust regarding confidentiality issues with the various online platforms

$>$ Reluctance or difficulty to find a space at home or elsewhere where confidentiality can be assured.

In addition to the client's resistances, there may also be resistances on our part, as therapists, be it for similar reasons, or for fear of not being able to help our clients as efficiently in a teletherapy encounter as we would in a face-to-face encounter. We must understand that for both therapists and clients, having to transition from a face-to-face therapeutic modality to virtual modality requires an effort. And when we consider that this effort may be coerced because of strict confinement requirements, this means that a certain resistance to change must be overcome by both.

On the other hand, because the pandemic has radically upset our lives, isolating us from one another, it is with gratitude that many clients have accepted to continue their therapeutic process through a virtual mode and have welcomed the possibility to still receive regular therapeutic support from their therapists through teletherapy. Most therapists, for their part, were happy to keep in touch with the clients who had agreed to pursue their therapeutic process within a teletherapy modality. The fact that teletherapy also made it possible for therapists to continue to receive a regular income, even if reduced, was considered an advantage. Hence, the adaptation effort required by the new situation was somewhat mitigated by non-negligible advantages for both therapists and clients, which, in most cases, helped overcome initial resistance to change for both parties. 


\section{Clinical Specifics to Consider in the Case of Teletherapy}

The modification of the therapeutic setting that teletherapy inevitably supposes may have come with surprises for therapists as well as clients. Indeed, because of the distance introduced by the virtual mode, some clients may have found it harder to freely express their feelings, while others may have presented a lower level of resistance than usual. The fact is, teletherapy introduces modifications of which we must be aware.

In a Newsletter recently put online (Spring, 2020) by the EAP (European Association for Psychotherapy) we can find concrete recommendations to help therapists make sure that their teletherapy interventions abide by the usual ethical standards in psychotherapy. In the same document, we also find useful observations with regards to specific clinical issues therapists need to be aware of. Here are some of these observations:

"People act differently online; you may have to adapt your theoretical perspective or clinical techniques to respond. In particular:

$>$ 'Digital natives' who have grown up with the online world, are much more familiar with it than 'digital immigrants' who have had to learn later in life

$>$ You will probably lose 'presence' with some clients - yet others will flourish and seem more intimate online - especially in phone or I.M. (instant message)

$>$ The 'online disinhibition effect' means that some people open up very quickly and more intensely online. This can be startling at first (https://www.research gate.net/publication/8451443_The_Online_Disinhibition_Effect).

$>$ As a result, defences and resistances can be much reduced:

$>$ The 'power differential' is changed to a much more equal relationship

$>$ You will not 'own' the therapy as much

$>$ Clients are often more 'natural' than in a face-to-face setting

$>$ They act more like 'customers' than 'patients'

$>$ Similarly, 'free association' should be seen as different online:

$>$ clients will be 'meeting' in their own space

$>$ they can show you photos, artefact, etc.

$>$ they can 'arrive' seated in different rooms at home - or in the garden

$>$ Clients can also use pets, cushions, food, etc. as defences.

However, all this is material to be considered and incorporated - not condemned."2

2 E-Newsletter EAP Draft Online Guidance, 2020 http://news.europsyche.org/eap_mem ber_information_20_covid-19/EAPonlineGuidance.pdf 


\section{How to Notice Defenses and Resistances in the Context of Teletherapy}

\section{Note: limitations of this article}

What I am about to develop in this article mainly applies to clients with whom we have developed a secure relationship and with whom we are already used to do body work in the context of face-to-face therapeutic work. As for myself, presently I do not feel comfortable to accept new clients who would want to do body work in the context of teletherapy. This is simply because I feel the need to first establish a relationship and experience body work with a new client in a face-toface setting. For me this is a "must" in order to be able to do body reading in a reasonable way, and to see firsthand how a new client reacts energetically and emotionally to body work proposals.

\section{Generalities}

As mentioned above, teletherapy deprives us of many precious cues when it comes to noticing resistances. As we know, in the case of online video sessions, the framing on the screen may let us see a close-up of the face and the upper part of the body, when we are having a verbal interaction with our client. That enables us to notice the facial expression, the quality of the gaze, and maybe a little bit of what is happening in the upper body. However, what is happening in the rest of the body totally escapes us, e. g. feet that may be shifting, nervous movements with the hands, etc. Conversely, when the framing on the screen allows us to see more of the body, as our client may be standing up, distant from the camera (oftentimes, we cannot see the feet), the details of the facial expression as well as the quality of the gaze, and even a sense of the quality of the breathing, now escape us.

As we know, facial expression, as well as various reactions in the rest of the body give us important cues telling us that a resistance is at work. For example: tense jaw, reduced breathing, subtle pulling back motions, averted gaze, various tensions in the body, etc. So how can we then compensate what we cannot directly observe in the course of an online video session?

\section{First case scenario:}

\section{viewing only the face and upper body during a verbal exchange}

During a verbal exchange in a seated position, the framing on the screen allows us to see the face and the upper part of the body of our client. The facial expression and the upper body posture can tell us a lot with regards to resistances. Howev- 
er, the rest of the body remains off-screen and cannot be seen. Because of that, we need to compensate by inviting our client to direct her ${ }^{3}$ awareness to what is happening in her body as we interact. We can ask her to pay attention to tensions, or to movements of impatience or nervousness. We can also invite her to notice the depth of her breathing, the quality of head/body connection, etc. The bottom line is: we must rely of the client's help to enable us "to see" her body, so to speak. Our observations combined with what the client can report on their somatic experience can bring into focus resistances that may manifest in various ways. In teletherapy as much as in face-to-face encounters, when a resistance is identified, it then becomes important to take a pause to explore it and to resolve it, if possible, before moving on.

\section{Second case scenario:}

viewing almost the entire body in a standing-up position

In the standing-up position, when the framing on the screen shows us almost the entire body of our client, the facial expression becomes much less accessible. In this case, we must supplement what is lost by training our ear to perceive the nuances in our client's voice (teary, quavering, strangled or hushed voice), especially when we invite her to hold a posture or to do expressive work. We should also notice when the voice sounds disconnected or mechanical. But here again, we will also need our client's help to enable us to identify resistances that may manifest. This can be done by inviting the client to remain aware of what is happening when emotions are emerging in the course of expressive work. Do they notice any specific tension due to resistance: tight throat, tension in the jaw, blocked breathing, cutting off sensations in parts of the body, emergence of fear following an intense emotional expression? Or, on the contrary, what can they report when nothing is happening during the session? Are they experimenting a difficulty to stay "present" and connected during the work? If so, what is going on? Again, these manifestations of a resistance must be addressed and attended to before moving on.

\section{Third case scenario: viewing the body only partially when the client is lying down}

At times we may invite our clients to do some work in the lying down position when the physical setting allows it. That may include intense mobilization,

3 The pronoun "her", rather than "his/her/they" is used. Obviously, the client may be of any gender. 
like kicking and doing a temper tantrum, if they are in a bedroom where a mattress is accessible. However, at least in my own experience, it may prove difficult for the client to position her computer or tablet or phone in such a way as to enable us to clearly see what is happening in the body while the client is doing work in the lying down position. We may only see portions of the body during the work. In that case, it will be even more essential to pay attention to the inflexions in their voice or to the sound of their breathing. Even more than in the first two case scenarios, we must regularly check with clients about what is going on for them during the work, as they pause after an exercise. Can they describe their sensations? Can they report on emotions that may have come up? Did they notice any kind of resistance while doing the exercise? When we invite a client to do some work in a lying down position, we need to remind ourselves that this bodily position may be conducive to a regressive state. Thus, we must make sure we are keeping a secure connection with our clients while helping them self-regulate and move though an exercise. The less we see the body or the facial expression, the more crucial it becomes to remain aware of what is going on for the client each step of the way. Otherwise we risk exposing our client to a re-traumatizing experience in the case of an intense emotional experience, instead of a productive one. We do not want that to happen because the effect would be a hardening of defenses and resistances.

\section{Fourth case scenario: therapy by phone}

Teletherapy by the mean of phone contact is a different kind of experience. Presently, the clients with whom I do therapy by phone are persons with whom I have had at least one year of face-to-face therapeutic work, if not much more. With some of these clients, I can do a great deal of body work, which continues to amaze me. With other clients, I cannot do as much. It depends on their setting and/or on the ease with which they feel comfortable to do body work within the phone session modality. One thing is for sure: therapy sessions by phone are radically different from online video sessions. The rapport is much more intimate. We can hear the other person's breathing, the emotional color in her voice, the eloquence of her silences, the hesitations in the speech, all of which may signal the emergence of a resistance or, on the contrary, the welling-up of an emotion. Given the fact that we do not see the body at all, it is important to frequently check out what is the bodily posture of the person, what kind of sensations she notices in his/her body, how is her breathing, how is the quality of her grounding. Again, it is necessary to regularly check how the client can self-regulate during the work. 


\section{Bottom line:} we need to be aware of our capacities and limitations in teletherapy

Teletherapy demands us to reassess our capacities and our limitations with regards to helping our clients move through their resistances and contain their experience. When we are in a face-to-face setting, we have many strategies at our disposal in the eventuality of an emotional flooding, a dissociation or a freezing response on the part of our client. This is not so much the case in a virtual encounter where our only resource to help a client contain and self-regulate may be our voice. Interestingly enough, in my experience, and in that of some of my colleagues, it appears that many clients are intuitively learning to self-regulate, knowing that they cannot count on our physical presence to help them contain and regulate their experience.

\section{Positive side effects}

In all the scenarios presented above, teletherapy requires us to rely much more on what the client can tell us about their sensations, their emotions and their general experience, including that of noticing resistances. One of the positive side effects of this practice has been to develop/reinforce in our clients their capacity to be self-aware. As a result, clients become more involved in their own therapeutic process as a proactive member of a "team", when they are invited to participate in the therapeutic "expertise" that is needed to enable them to evolve in their process.

\section{Additional Reflections on the Work with Resistances in Teletherapy}

\section{Resistances and reality factors in teletherapy}

In the context of teletherapy, sometimes resistance should be put into perspective, as some resistances may be triggered because of the setting in which the clients find themselves. For example, a client who refrains from voicing loudly during expressive work on anger may be concerned that her young child, her husband or neighbours may be hearing her. Of course, such reluctance to voice loudly may also be part of the client's typical characterological defense system. However, although an element of reality should be acknowledged to explain the resistance, this reality factor due to the setting (client being in her home) may nevertheless offer an opportunity for exploring analytically the meaning of the client's resistance. For example, the therapist can ask: "Who was it you 
were afraid could hear you when you were voicing your anger as a child? Whom might have you been afraid to upset?" etc. In a word, even though a resistance may partly be "justified" by a reality factor, it still needs to be analyzed if we want to help our client gain a deeper understanding of her characterological patterns.

\section{Different physical setting, different props and resistances ... from both sides}

In our offices we have at our disposal all the props, or instruments, we deem useful to do body work with our clients: breathing stool, mattresses, towels, blankets, rolls, gym ball, etc. When doing teletherapy, our clients are in their own setting and may not have the same props at their disposal. This can be a motive for them to not do certain exercises. For the therapist, it may prove difficult to assess whether the client is avoiding doing a specific exercise because of resistance or simply because they do not have the necessary conditions to properly do the exercise. Whatever the case, the best response on the therapist's part would be to adapt body work proposals to the client's physical environment and see if that helps them move beyond whatever resistance they may have for doing a specific exercise.

But it may well be that the resistance would come from the therapist in the guise of refraining to propose some energetic work strategies, concluding beforehand that certain strategies cannot be used, without even trying. Chances are the therapist would then tend to fall back on verbal interactions while doing minimal energetic work, which could be a form of collusion with the client's resistances.

\section{Attitudes to keep in mind when working with resistances in the context of teletherapy}

In teletherapy, it is as important to confront resistances as it is in a face-to-face setting. However, it is important to do so with sensitivity, precisely because the client cannot count on our physical presence to help them contain and self-regulate if there are reactions of emotional flooding, freezing or dissociation following an upsetting intervention. This is especially the case with clients who come to us with early issues and with a history of trauma who may experience a collapse, even momentarily, of the defense system if their resistances are confronted in a brutal way.

That is not to say that we should err on the side of complacency and collude with the client's defenses. Defenses and resistances must be pointed out 
and recognized such. Once named, the therapist can evaluate to what extent the client is ready and open to explore these resistances. If they are open to such exploration, it will be possible to invite the client to openly express a resistance using body work techniques, even in the context of teletherapy. This type of work is most useful to help the client understand: 1) the function of his/her defenses and resistances, 2) the context within which they have started to take shape historically, and 3) what do they mean with regards to their therapeutic process.

\section{Some Research Data Comparing Face-to-Face and Teletherapy Interventions}

As we have experienced, those of us who had to adapt to this new therapeutic modality, teletherapy has challenged us in various ways. Because of the pandemic we were obliged to rethink our interventions due to sanitary restrictions. However, the various technological means at our disposal have fortunately enabled us to continue our work with many of our clients. Some of us were even surprised to see the extent of what could be accomplished with clients within this new therapeutic modality.

As we conclude, it is interesting to highlight some research data regarding the efficiency of teletherapy compared to face-to-face therapy as well as its impact on the quality of the relationship. Recently, I took a two-and-a-half hour continuing education online workshop offered by the Order of Psychologists of Quebec. This workshop was offered by Dr. Stéphane Bouchard, who is the head of a Canadian research committee on cyberpsychology. In that online workshop, Dr. Bouchard presented a variety of research data comparing the two modalities: teletherapy v. face-to-face psychotherapy. These data tend to demonstrate that there is no significant difference between the two types of interventions when measuring: a) the quality of the therapist-client relationship, as well as, b) the efficiency of the interventions. (Dr. Bouchard's Charts, illustrating these conclusions, are attached as an Appendix to this article). True, most studies that are reported by Dr. Bouchard were conducted in the context of CBT interventions. However, he presented at least one study that was conducted in the context of psychodynamic analytical interventions, which is closer to the kind of therapy we practice, and the research data gave a similar result.

These data are encouraging for those of us who had to adapt our interventions to the teletherapy modality. But regardless of the kind of work we are doing within this modality, there are two major key abilities we still need to cultivate if we are to ensure the quality of our therapeutic work, and these abilities are: 
$>$ The quality of attunement we can offer our clients even from a distance

$>$ The attention devoted to our clients' capacity for self-regulation during the work

Displaying these abilities supposes a high quality of presence on our part as therapists. As most of us have probably found out, maintaining a high quality of presence is challenging when doing online video sessions (for some of us, it seems this is less the case when doing sessions by phone). Online video sessions can be exhausting in various ways.

A colleague from Massachusetts ${ }^{4}$, has shared with us a document from a therapist named Rosemary Gaddum Gordon (2020) that offers concrete suggestions, especially regarding the prevention of visual tiredness. I find these suggestions relevant to the topic of my article because I believe that visual tiredness may prevent us from noticing cues that can indicate that a resistance is at work, not to mention the fact that visual tiredness may play into our own resistances as we become less alert, less proactive and possibly less present. Maybe many of us already apply these suggestions in our practice, but I thought it might be useful as a reminder, to include them here.

\section{Video Streaming and Your Eyes}

Avoid:

$>$ Staring at the screen

$>$ Narrowing the visual field

$>$ Reduced breathing

$>$ A rigid body

Ways and means:

$>$ Sit so you can breathe deeply and easily. Support your back so you can be comfortably upright.

> Set up your screen so that you have plenty of space behind the monitor; you can face into a room or towards a window that doesn't get direct sunlight, for example. This allows for a more 3D experience, which helps your eyes focus more easily. It allows your peripheral vision to be more stimulated, which in turn helps you not to over-focus or narrow either the depth or breadth of your visual field.

$>$ Avoid staring because it reduces the movement of the eyes. When the eyes are not moving freely, we do not see as well. Staring in this sense is a mental state; we "park" the eyes while the mind has become visually disengaged. If the train of thought is useful, however, you can close your eyes or look away from the screen while you follow it.

4 Susan Kanor, IIBA Faculty member. 
$>$ Blink frequently, about once every 5 seconds. When we concentrate, we tend to blink less, and we need the blinks to both cleanse and lubricate the eyes as well as to belp us not to "stare" at the image.

$>$ Be curious, look at the details on the screen rather than trying to take it all in at once. If it's just a face, for example, look at the particulars of that face as if you were going to sketch it.

- Change your focal distance often; look out of a window or around the room every 5 minutes or so. If possible, look at objects that are at least 20 feet away. It is less distracting to the other person, when our eyes are aimed at a view seen just above the screen.

> Don't sit too close. Avoid straining. I suggest you sit at about arm's length from the screen. If you need glasses, figure out which ones are best for this situation, experiment. Wear the weakest prescription that allows you to see comfortably and encourages you to relax.

- In large gatherings it is often acceptable to stop your video for a few minutes. This allows you to get up, stretch, swing and/or palm to rest your eyes.

$>$ When you get up and move about, let yourself notice the apparent motion of the furniture or the view out of the window. Again this will stimulate your peripheral vision and allow your eyes to relax and your mind to be more open.

> Move, wriggle in your chair. Avoid getting stuck in one position. Just like the eyes, the body needs to move to stay comfortable. Some people like gel pillows or gym balls because they encourage constant micro-adjustments and keep the body alert. Standing desks are also excellent for this reason.

$>$ We all take in and process information differently. Some of us look upwards when we're picturing something, at other times we look sideways or downwards as we access other areas of our brain. It is all normal and we need to both allow ourselves to look away from the screen, as well as allow others to do the same. In normal in-person conversations we often look around as we speak. On the screen it just becomes more obvious.

(Rosemary Gaddum Gordon, 2020)

\section{Conclusion}

Finally, I would like to share with you one last quote that another colleague from Texas ${ }^{5}$ has shared with us. It is a quote from Dr. Gianpiero Petriglieri (2020), a medical doctor and psychiatrist who is an associate professor of organizational behavior at INSEAD in France. This quote highlights the phenomenon of general tiredness we experience when we do videotherapy online.

5 Barbara Davis, IIBA Faculty member. 
It is especially eloquent for us bioenergetic analysts for whom bodily sensations are so central:

"I spoke to an old therapist friend and finally understood why everyone is so exhausted after video calls. It's the plausible deniability of everyone's absence. Our minds are tricked into the idea of being together when our bodies feel we're not. Dissonance is exhausting. It's easier being in each other's presence, or each other's absence, than in the constant presence of each other's absence. Our bodies process so much context, so much information, in encounters, that meeting on video is being a weird kind of blindfolded. We sense too little and can't imagine enough. That single deprivation requires a lot of effort."

I wish you good continuation in your teletherapy practice. Even though many of us may have started again to see some of our clients face to face, other clients may decide that they prefer to continue their work though teletherapy or through a mix of face-to-face and teletherapy. One thing is for sure: what we will have learned due to the confinement and the necessity to adapt our clinical practices will have transformed us into more attentive, more flexible and more resilient therapists.

\section{References}

Bouchard, S. (2020). Psychothérapie par vidéoconférence (PVC): efficacité, alliance thérapeutique et informations pratiques. Online continuing education course. Order of Psychologists of Quebe (paid activity accessible to OPQ members).

European Association for Psychotherapy. (2020). EAP Online Guidance. Interim Advice for Conducting Psychotherapy Online. http://news.europsyche.org/eap_member_ information_20_covid-19/EAPonlineGuidance.pdf

Gaddum, R.G. (2020). Holistic Vision Improvement. Self-Regulation Therapy. https:// visioneducators.com/setting-up-your-computer-screen-to-support-good-vision

Petriglieri, G. (2020). How to Deal with Video Calls, Zoom Fatigue, and Remote Relationships. A Q\&A with Gianpiero Petriglieri, MD. https://goop.com/wellness/mindfulness/zoom -fatigue

\section{About the Author}

Louise Fréchette is a clinical psychologist, bioenergetic analyst and member of the IIBA Faculty. She is in private practice in Montreal, Canada. Louise has taught as a Faculty member in Canada, USA, France, Belgium, Spain, Russia, Argentina, Brazil and New Zealand, and has been a keynote speaker and panellist at IIBA Conferences. She has also trained in Psychosynthesis and in Eriksonian hypnosis.

louisefrechette@videotron.ca 


\section{Appendix \\ Charts from Dr. Stéphane Bouchard's online course}

These charts compare efficacy of face to face vs. video therapy sessions with various types of problems as well as the quality of the therapeutic relationship in both modalities

\section{Grise:}

Étude aux USA avec assignation aléatoire et avec

des cas de dépression majeure (stubbing et al., 2013)

Assignation aléatoire d'adultes souffrant de dépression majeure

(8) et de troubles d'anxiété (7): 14 en PVC et 12 en F-à-F.
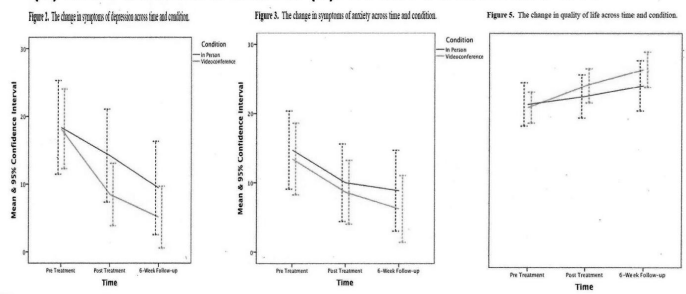

Comparative efficacy in cases of severe depression and anxiety; Left hand chart: diminution of symptoms of depression; Center chart: diminution of symptoms of anxiety; Right hand chart: improvement of quality of life

\section{Ereser}

TPA - Qualité de la relation thérapeutique

(Allard et al. 2007)

WAI - Relation thérap.

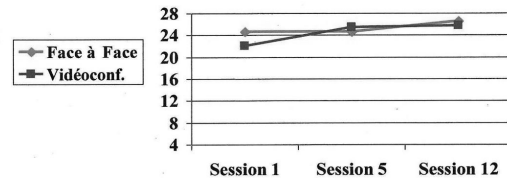

Comparative quality of therapeutic relation-

\begin{tabular}{lllcl}
\hline & $\boldsymbol{F}$ & Sig. & Eta carré partiel & Taille d'effet \\
\hline Temps & 7.85 & .000 & .13 & Moyen \\
Condition & 2.25 & ns & .04 & Petit \\
Interaction & 1.74 & ns & .03 & Petit \\
\hline
\end{tabular}
ship; Face-to-Face: top line; Video sessions: bottom line 